\title{
Neprilysin-2 Is an Important $\beta$-Amyloid Degrading Enzyme
}

Daniel Hafez, ${ }^{*}$ Jeffrey Y. Huang, ${ }^{*}$

Alexis M. Huynh, ${ }^{*}$ Stephanie Valtierra, ${ }^{*}$ Edward Rockenstein, ${ }^{\dagger \neq}$ Angela M. Bruno, ${ }^{*}$ Bao Lu, ${ }^{\S}$ Luc DesGroseillers, ${ }^{\natural}$ Eliezer Masliah, ${ }^{\dagger \neq}$ and Robert A. Marr*

From the Department of Neuroscience, ${ }^{*}$ Rosalind Franklin University of Medicine and Science, North Chicago, Illinois; the Departments of Neurosciences ${ }^{\dagger}$ and Pathology, ${ }^{\ddagger}$ University of California, San Diego, La Jolla, California; Children's Hospital, ${ }^{\S}$ Harvard Medical School, Boston Massachusetts; and the Department of Biochemistry, "Iniversity of Montreal, Montreal, Quebec, Canada

Proteases that degrade the amyloid- $\beta$ peptide (A $\beta$ ) are important in protecting against Alzheimer's disease (AD), and understanding these proteases is critical to understanding AD pathology. Endopeptidases sensitive to inhibition by thiorphan and phosphoramidon are especially important, because these inhibitors induce dramatic $A \beta$ accumulation ( $\sim 30$ - to 50 -fold) and pathological deposition in rodents. The $A \beta$-degrading enzyme neprilysin (NEP) is the best known target of these inhibitors. However, genetic ablation of NEP results in only modest increases ( $\sim 1.5$ - to 2 -fold) in $\mathrm{A} \beta$, indicating that other thiorphan/phosphoramidon-sensitive endopeptidases are at work. Of particular interest is the NEP homolog neprilysin 2 (NEP2), which is thiorphan/ phosphoramidon-sensitive and degrades $A \beta$. We investigated the role of NEP2 in A $\beta$ degradation in vivo through the use of gene knockout and transgenic mice. Mice deficient for the NEP2 gene showed significant elevations in total $\mathbf{A} \beta$ species in the hippocampus and brainstem/diencephalon ( $\sim 1.5$-fold). Increases in $A \beta$ accumulation were more dramatic in NEP2 knockout mice crossbred with APP transgenic mice. In NEP/NEP2 double-knockout mice, $A \beta$ levels were marginally increased $\left(\sim 1.5-\right.$ to 2 -fold), compared with $\mathrm{NEP}^{-/-}$, $\mathrm{NEP2}^{+/+}$controls. Treatment of these double-knockout mice with phosphoramidon resulted in elevations of $A \beta$, suggesting that yet other NEP-like A $\beta$-degrading endopeptidases are contributing to $\mathrm{A} \beta$ catabolism. (Am J Pathol 2011, 178:306-312; DOI: 10.1016/j.ajpath.2010.11.012)
Alzheimer's disease $(A D)$ is a neurodegenerative disorder currently affecting more than 26 million people worldwide and, as advances in modern medicine prolong lifespan, this number is expected to quadruple by $2050 .{ }^{1} \mathrm{~A}$ major factor believed to be involved in the progression of $A D$ pathology is the accumulation of amyloid- $\beta$ peptide $(A \beta)$. Studying the mechanisms of $A \beta$ clearance is, therefore, very important to understanding $A D$.

Currently, enzymatic degradation is thought to play an integral role in the removal of $A \beta$. Of the $A \beta$-degrading enzymes, neprilysin (NEP) has been shown to be highly critical for cerebral $A \beta$ control. ${ }^{2}$ NEP expression has also been inversely correlated with amyloid pathology in humans and mice, and NEP gene transfer has been reported to reduce amyloid pathology in transgenic mice (reviewed by Marr and Spencer ${ }^{3}$ ). Despite the importance of NEP-mediated A $\beta$ degradation, NEP knockout $(\mathrm{KO})$ mice show only moderately elevated $A \beta$ levels (1.5to 2-fold), insufficient to cause plaque deposition. ${ }^{4}$ However, when treated with thiorphan, an NEP endopeptidase inhibitor, mice and rats demonstrate pathological accumulations of $A \beta$ after only 1 month. 2,5 This was also found in mice treated with phosphoramidon, another NEP inhibitor. ${ }^{6}$ These results indicate that there may exist additional NEPlike endopeptidases in the metalloprotease 13 (M13) family that are central to the $A \beta$ clearance pathway.

The NEP homolog neprilysin 2 (NEP2) is one such endopeptidase. NEP2 (also known as MMEL1/2, SEP, NL1, NEPLP) possesses a $55 \%$ sequence identity to NEP and has been shown to degrade vasoactive peptides. ${ }^{7,8}$ In addition, the membrane-bound $\alpha$-splice form of murine NEP2 has demonstrated $A \beta$-degrading properties in membrane fractions. ${ }^{9}$ In transduced HEK293T cells, our research group previously showed that cell surface human NEP2 ( $\beta$-splice form) was able to degrade both $A \beta_{42}$ and $A \beta_{40}$ peptides. ${ }^{10}$ Subcellular localization studies using transfection into $\mathrm{CHO}$ cells have found that murine NEP2 is present primarily in the

Accepted for publication September 23, 2010.

Supplemental material for this article can be found on http://ajp. amjpathol.org or at doi:10.1016/j.ajpath.2010.11.012.

Address reprint requests to Dr. Robert A. Marr, Ph.D., Department of Neuroscience, Rosalind Franklin University of Medicine and Science, 3333 Green Bay Rd., North Chicago, IL 60064. E-mail: robert.marr@ rosalindfranklin.edu. 
endoplasmic reticulum. ${ }^{7,11}$ However, Oh-Hashi and colleagues $^{12}$ did find murine NEP2 activity at the cell surface. Studies of NEP2 in mice and rats have demonstrated that it is expressed primarily neurons and shows mild expression in the cerebral cortex, mild to moderate expression in the hippocampus, and strong expression in numerous thalamic, hypothalamic, and brainstem nuclei. ${ }^{13-15}$ In mice, however, expression in the hippocampus could not be confirmed, because of high background levels. ${ }^{15}$ NEP2 is involved in sperm function in mice and modulates fertilization and early embryonic development. ${ }^{16}$ However, NEP2 also functions as a neuropeptidase, one that is possibly involved in several physiological pathways controlling nociception, energy, and endocrine functions. ${ }^{15,17,18}$

The purpose of this study was to investigate the in vivo role of NEP2 in A $\beta$ degradation in mice. Using NEP2 $\mathrm{KO}^{16}$ and NEP/NEP2 double-knockout (DKO) mice, the importance of NEP2 was investigated by measuring $A \beta$ levels in various regions in the brain of $\mathrm{KO}$ and control mice. In addition, APP transgenic mice crossed with NEP2 KO mice were used to test the effect of NEP2 on A $\beta$ removal when challenged with high $A \beta$ levels. Defining the role of NEP2 in $A \beta$ clearance will provide further insight into $A D$ pathogenesis and possible therapies for this disease.

\section{Materials and Methods}

\section{Animals}

All mice were used according to institutional Animal Care and Use Committee-approved protocols and in accordance with the Guide for Care and Use of Laboratory Animals as published in 1996 by the U.S. National Academy of Sciences. NEP2 (Mme/1) KO mice ${ }^{16}$ were obtained from the laboratory of Dr. Luc DesGroseillers. NEP/NEP2 DKO mice were created by cross-breeding NEP2 KO mice (129 background) with NEP (Mme) KO mice (BALB/c background) (received from the laboratory of $\mathrm{Dr}$. Bao Lu). ${ }^{19}$ These mice were backcrossed once more with the NEP KO mice (BALB/c background) before being maintained by inbreeding $\mathrm{NEP}^{-/-} /$ $\mathrm{NEP} 2^{+/+}$or NEP ${ }^{-/-} / \mathrm{NEP}^{-/-}$strains. APPtg/NEP2 KO mice were created by cross-breeding NEP2 KO mice (129 background) with APPtg mice (TASD41 line, received from the laboratory of Dr. Eliezer Masliah) (Blk/Sw background). ${ }^{20}$ These mice are propagated by breeding heterozygous APP transgenic mice having either wild-type or NEP2 ${ }^{-1-}$ backgrounds with wild-type (129) or NEP2 $2^{-/}$(129) mice, respectively. The analysis was done with mice that had been backcrossed three times with the 129 lines.

Mouse genotypes were confirmed by PCR analysis. Briefly, NEP2 gene knockout mice were identified using a specific primer set (wt-F: 5'-TGGAACTGGAGACGCATCTGG-3', Neo-F: 5'-TCCTGTCATCTCACCTGGCTCC-3', NL1-R: 5'-TAGCTCCATCAGGTCCATTCG-3'): APPtg mice were identified by using a specific primer pair (APPtg-F: 5'-GGCTACGAAAATCCAACCTACAAG-3', APPtg-R: 5' GATGATGGCATGCAGCACTGG-3'); and NEP KO mice were identified using a specific primer set (Exon12-F: 5'GAAATCATGTCAACTGTG-3', Neo-R: 5'-ATCAGAAGCTTATCGAT-3', Exon13-R: 5'-CTTGCGGAAAGCATTTC-3'). Ex- amples of PCR genotyping results are presented in Supplemental Figure S1 (at http://ajp.amjpathol.org).

\section{A $\beta$ Enzyme-Linked Immunosorbent Assay}

Mice were anesthetized with 2-bromo-2-chloro-1,1,1-trifluoroethane (Sigma-Aldrich, St. Louis, MO) and were sacrificed by cervical dislocation for $A \beta$ analysis. Brains were extracted and dissected into four regions: cerebellum, brainstem/diencephalon, hippocampus, and cerebral cortex. Samples were stored at $-80^{\circ} \mathrm{C}$ until analysis. Frozen brain sections were homogenized in lysis buffer $(5 \mathrm{~mol} / \mathrm{L}$ guanidine $\mathrm{HCl}$; Fisher Scientific, Pittsburgh, PA) using a Polytron homogenizer (Kinematica, Bohemia, NY). Quantification of $A \beta_{1-40}$ and $A \beta_{1-42}$ was performed using isoformspecific $A \beta$ enzyme-linked immunosorbent assay (ELISA) kits (Wako Chemicals, Richmond, VA) ${ }^{4}$ Statistics were determined using two-tailed Student's $t$-test compared with control.

\section{Immunohistochemistry}

Mouse hemibrains were placed in $4 \%$ paraformaldehyde (Fisher Scientific) fixative for 24 hours before storage in a cryoprotectant solution ( $30 \%$ sucrose, $0.1 \mathrm{~mol} / \mathrm{L} \mathrm{PO}_{4}$ ). Fixed hemibrains were sagittally sectioned on a freezing microtome $(40 \mu \mathrm{m})$ and stored in a cryoprotectant solution at $-20^{\circ} \mathrm{C}$. Every sixth brain slice was selected for pretreatment with $70 \%$ formic acid for 10 minutes. After application of the primary antibody (4G8, 1:1500, Sigma-Aldrich), samples were incubated for 48 hours at $4^{\circ} \mathrm{C}$ before applying secondary antibody (Alexa Fluor 488 goat anti-mouse 1:250, or Alexa Fluor-594 goat anti-mouse 1:250; Invitrogen, Carlsbad, CA) and were imaged by fluorescent microscopy (Microscopy and Imaging Facility, Rosalind Franklin University of Medicine and Science, North Chicago, IL). A $\beta$ plaque burden was quantified by averaging the percent area staining positive (above threshold) within the entire specified brain region from several sections per animal, using MetaMorph software (Molecular Devices, Sunnyvale, CA). Intracellular $A \beta$ was also measured by averaging the percent area staining positive (excluding plaques) in the cortex or in the CA fields of the hippocampus. ${ }^{21}$ Statistics were determined using two-tailed Student's $t$-test compared with control.

\section{In Vitro $A \beta$ Degradation Assay}

The murine NEP2 $\alpha$ cDNA construct was generated by PCR mutagenesis (as previously described) ${ }^{22}$ of the murine NEP2 $\beta$ cDNA, to delete the alternative exon missing in murine NEP2 $\alpha .{ }^{10}$ Sequencing analysis confirmed the correct deletion (Northwestern Genomics Core Facility, Northwestern University, Chicago, IL). For the assay, conditioned medium containing $A \beta$ was first collected from supernatants of HEK293T cells transfected with a mutant APP expression plasmid, as previously described. ${ }^{23}$ HEK293T cells were then transfected (calcium-phosphate method) ${ }^{24}$ with expression plasmids for murine NEP $2 \alpha$, human NEP, or green fluorescent protein (GFP). Two days after transfection, cell medium was re- 
placed with conditioned medium containing $A \beta_{42}$ (50 $\mathrm{pmol} / \mathrm{L}$ ) with or without $100 \mu \mathrm{mol} / \mathrm{L}$ thiorphan $(\mathrm{T})$. After 5 hours of incubation at $37^{\circ} \mathrm{C}\left(10 \% \mathrm{CO}_{2}\right)$, supernatants were collected, centrifuged to remove cell debris (1000 $\times g, 5$ minutes), and quantified using A $\beta$ ELISA (as described above). Statistics were determined using twotailed Student's t-test compared with control (GFP).

\section{Intracerebroventricular Infusion of Phosphoramidon}

Mice (NEP/NEP2 DKO) were anesthetized using isoflurane and placed on a stereotaxic frame with an isoflurane nose cone (Kopf Instruments, Tujunga, CA). Miniosmotic perfusion pumps (Alzet model 1007; Durect, Cupertino, CA) were implanted subcutaneously on the dorsal aspect of each mouse. Pump cannulae were placed into the lateral ventricle for delivery of drug or vehicle. Pumps delivered $10 \mathrm{mmol} / \mathrm{L}$ phosphoramidon $(0.11 \mu \mathrm{L} / \mathrm{hr})$ in saline containing $1 \mathrm{mmol} / \mathrm{L}$ ascorbic acid. Mice were sacrificed for analysis 2 weeks after implantation and $A \beta$ was extracted and quantified as described above.

\section{Real-Time PCR Assay of NEP2 Expression}

Total RNA was extracted using TRIzol (Invitrogen), treated with DNase (RNase free; Ambion, Austin, TX), and then reverse-transcribed into cDNA using a mix of oligo-dT and random primers (high-capacity CDNA reverse transcription kit; Applied Biosystems, Foster City, CA). QRT-PCR was performed with SYBR Green PCR master mix (Applied Biosystems) and analyzed using the comparative $\Delta \Delta$ Ct method (normalized to the amplification cycle counts of a house-keeping gene, cyclophilin A). Primer
A
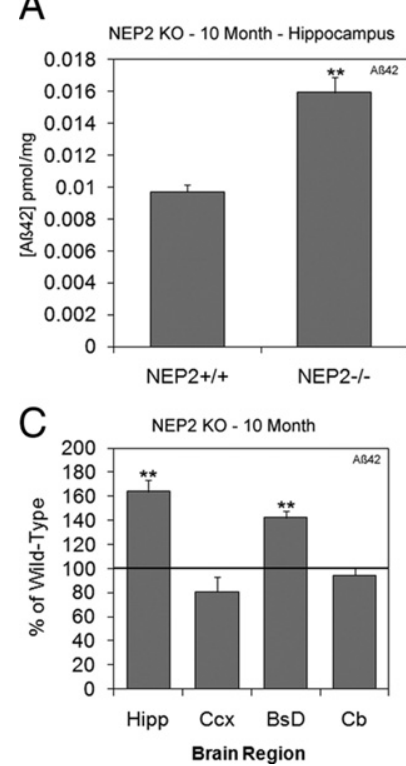

B

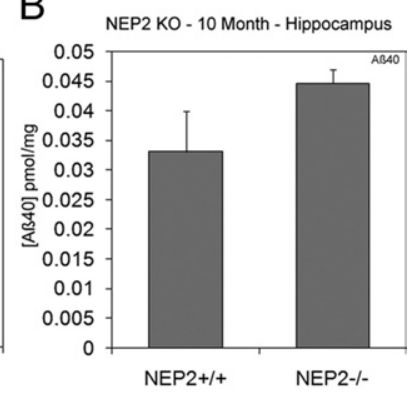

D

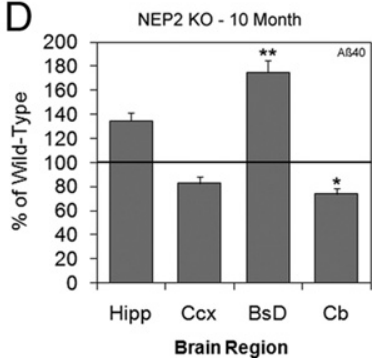

Figure 1. Amyloid $\beta(\mathrm{A} \beta$ ) levels are increased in NEP2 knockout (KO) mice. Total $\mathrm{A} \beta_{42}(\mathbf{A})$ and $\mathrm{A} \beta_{40}(\mathbf{B})$ levels in the hippocampus of 10-month-old NEP2 wild-type $(+/+)(n=9)$ and NEP2 KO $(-/-)(n=7)$ mice. Relative levels of $\mathrm{A} \beta_{42}(\mathbf{C})$ and $\mathrm{A} \beta_{40}(\mathbf{D})$ are reported as a percentage of wild-type mice from hippocampus (Hipp), cerebral cortex (Ccx), brainstem/diencephalon (BsD), and cerebellum $(\mathrm{Cb})$. Values are averages \pm SEM. ${ }^{*} P<0.05,{ }^{* * *} P<0.01$. pairs for NEP2 were, 5'-CCCAGGAAAAGGCCATGAAT-3' and 5'-CCAGGTGTTTATTGTTATCTTCCAAA-3'. Primers pairs for cyclophilin A were, 5'-GGCCGATGACGAGCCC$3^{\prime}$, and 5'-TGTCTTTGGAACTTTGTCTGCAAAT-3'.

\section{Results}

\section{Increased A $\beta$ Levels in NEP2 KO Mice}

To determine whether NEP2 is required for cerebral control of $A \beta$, we analyzed $A \beta$ levels in NEP2 KO mice. ${ }^{16}$ Total $A \beta$ extracts from different brain regions (hippocampus, cerebral cortex, brainstem/diencephalon, and cerebellum) were assayed for $A \beta_{42}$ and $A \beta_{40}$ levels by highly sensitive and specific ELISA. ${ }^{4}$ At 10 months of age, mice deficient in NEP2 demonstrated significantly increased $A \beta$ levels, compared with control NEP2 ${ }^{+/+}$littermates (Figure 1). In the hippocampus, only $A \beta_{42}$ levels were significantly elevated (measures of $A \beta_{42}$ and $A \beta_{40}$ levels in the hippocampus are presented in Figure $1, A$ and $B$, respectively). In addition to the hippocampus, $A \beta$ levels in the brainstem, cerebral cortex, and cerebellum were analyzed, with the data presented as the percentage of the average levels found in control $\left(\mathrm{NEP}^{+/+}\right)$mice (Figure 1 , $C$ and $D)$. In the brainstem/diencephalon, both $A \beta_{42}$ and $A \beta_{40}$ levels were elevated (Figure 1, C and D).

\section{Increased A $\beta$ Levels in APPtg/NEP2 KO Mice}

To determine the importance of NEP2-aided $A \beta$ degradation when exposed to high $\mathrm{A} \beta$ load, NEP2 ${ }^{-1-}$ mice were crossbred with an APP transgenic (APPtg) mouse line (TASD41 ${ }^{20}$ to generate APPtg/NEP2 ${ }^{-1-}$ mice. The APP transgenic line produced approximately an 80-fold increase in $A \beta_{40}$ levels, as can be observed by comparing the levels of $A \beta$ in the hippocampus from normal APPtg/NEP2 $2^{+/+}$mice (Figure 2B) to wild-type NEP2 $2^{+/+}$ mice (Figure 1B). $A \beta_{40}$ levels in the hippocampus demonstrated more than a fourfold increase in the absence of NEP2, compared with control mice (Figure 2B). It should also be noted that, although the difference was not statistically significant, levels of $A \beta_{42}$ and $A \beta_{40}$ in the cerebral cortex were measured at an average $19 \pm 9$ and $7 \pm$ 5 times the control mice, respectively (Supplemental Figure S2, at $h$ ttp://ajp.amjpathol.org).

To visualize the pathological effect of a NEP2 knockout in APPtg mice, immunohistochemistry was performed to detect deposited $A \beta$. The data indicate $A \beta$ plaque deposition elevated in the cortex of APPtg/NEP2 ${ }^{-1-}$ mice, compared with controls (Figure 3). Plaques were also observed in the hippocampus. Quantification of the percent area staining positive for $A \beta$ showed increased plaque deposition in the cerebral cortex (Figure 3D). Immunohistochemical analysis of the accumulation of intracellular $A \beta$ showed no significant differences between $\mathrm{NEP}^{+/+}$and NEP2 ${ }^{-l-}$ groups in the cerebral cortex and hippocampus (see Supplemental Figure S3, at http://ajp.amjpathol.org). However, the antibody used (4G8) recognizes cell-associated APP and other fragments, which may obscure the detection of elevated intracellular A $\beta$. Altogether, these data complement the findings of the NEP2 KO experiments (Fig- 
A

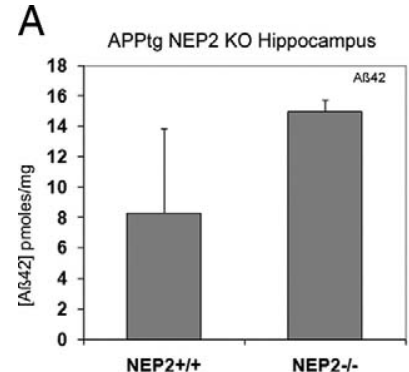

B
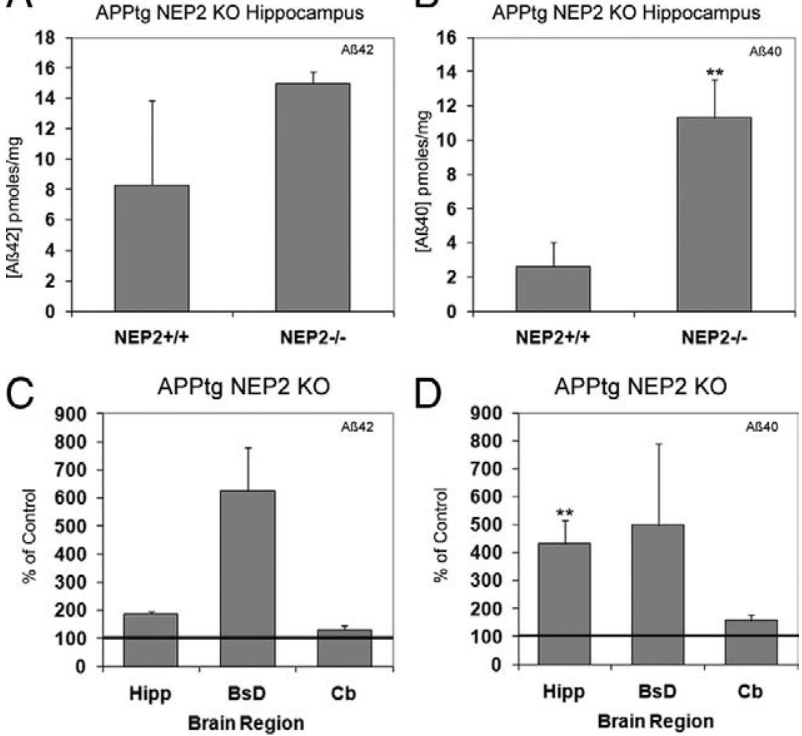

Figure 2. $\mathrm{A} \beta_{40}$ levels are increased in the absence of NEP2 in APPtg mice. Total $\mathrm{A} \beta_{42}(\mathbf{A})$ and $\mathrm{A} \beta_{40}(\mathbf{B})$ levels in 10-month-old APPtg mice in the presence $(+/+)(n=4)$ and absence $(-/-)(n=5)$ of the NEP2 gene. Relative levels of $\mathrm{A} \beta_{42}(\mathbf{C})$ and $\mathrm{A} \beta_{40}(\mathbf{D})$ are reported as a percentage of $\mathrm{APPtg} / \mathrm{NEP} 2^{+/+}$control mice from the hippocampus (Hipp), brainstem/diencephalon (BsD), and cerebellum $(\mathrm{Cb})$. Values are averages \pm SEM. ${ }^{* *} P<0.01$.

ure 1) and strengthen the conclusion that NEP2 plays a fundamental role in $A \beta$ degradation. Finally, real-time PCR gene expression analysis revealed no significant increase in the expression levels of the NEP2 gene associated with the presence of the APP gene (see Supplemental Figure S4, at $h$ ttp://ajp.amjpathol.org).
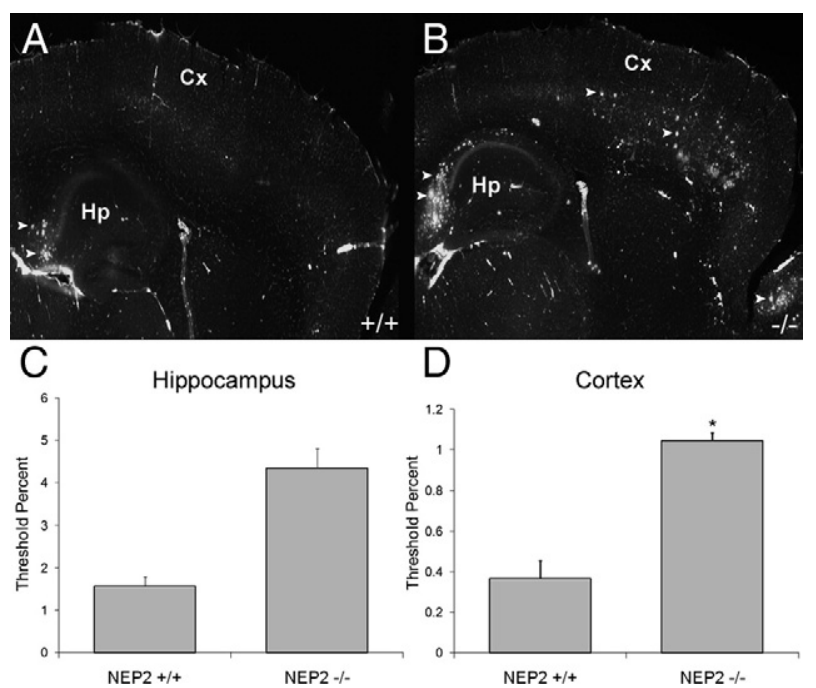

Figure 3. A $\beta$ plaque deposition is increased in the absence of NEP2 in APPtg mice. Representative fluorescent images of immunohistochemistry staining of deposited $\mathrm{A} \beta$ (green) from sagittal brain sections from APPtg/NEP2 ${ }^{+/}$ mice $(\mathbf{A})$ and $\mathrm{APPtg} / \mathrm{NEP} 2^{-/-}$mice $(40 \times)(\mathbf{B})$. Arrowheads indicate examples of plaques. Cx, cerebral cortex; Hp, hippocampus. Quantitation of the $\%$ area staining positive for plaque deposition in the hippocampus $(\mathbf{C})$ and cerebral cortex $(\mathbf{D})$ from APPtg/NEP2 ${ }^{+/+}$mice $(n=4)$ and APPtg/NEP2 ${ }^{-/-}$mice $(n=$ 5). Values are averages \pm SEM. ${ }^{*} P<0.05$.

\section{Decreased $A \beta_{42}$ Levels in Supernatants of mNEP2 $\alpha$ Transfected Cells}

The data presented above indicate that NEP2 controls both $A \beta_{42}$ and $A \beta_{40}$ levels in the brain. However, previous studies in mice have reported that murine $\operatorname{NEP} 2 \alpha$ (the only splice form active against $A \beta$ ) degraded $A \beta_{40}$ with much higher efficiency than $A \beta_{42} \cdot{ }^{9}$ Therefore, we set out to determine the $A \beta_{42}$-degrading activity of murine NEP2 $\alpha$ in our cell culture assay. ${ }^{10}$ HEK293T cells were transfected with expression plasmids for murine $\operatorname{NEP} 2 \alpha$, human NEP, or GFP, and then overlaid with $A \beta$-conditioned medium (containing $50 \mathrm{pmol} / \mathrm{L} A \beta_{42}$ ). A $\beta_{42}$ levels of transfected cell supernatants, with and without thiorphan $(100 \mu \mathrm{mol} / \mathrm{L})$ pretreatment, were measured by specific ELISA (Figure 4). Both mNEP2 $\alpha$ and hNEP transfected cell supernatants showed decreased levels of $\mathrm{A} \beta_{42}$ compared with the GFP control $(P<0.01)$. Addition of the NEP-like inhibitor thiorphan abolished the ability of mNEP $2 \alpha$ and hNEP to degrade $A \beta$, confirming the identity of the endopeptidase activity. These in vitro data demonstrate the ability of NEP $2 \alpha$ to degrade $A \beta_{42}$, corresponding with our data from the mouse studies.

\section{Increased A $\beta$ Levels in NEP/NEP2 DKO Mice}

With the effects of NEP2 KO on A $\beta$ levels identified, we next sought to determine the consequence of deficiencies in both NEP and NEP2 on A $\beta$ levels. NEP KO mice ${ }^{19}$ were crossed with NEP2 $\mathrm{KO}$ mice $^{16}$ to generate NEP/ NEP2 DKO mice. Both 10-month-old and 14-month-old $\mathrm{NEP}^{-1-}$ NEP2 $^{-/-}$DKO mice demonstrated increased $\mathrm{A} \beta$ levels, compared with $\mathrm{NEP}^{-/-} / \mathrm{NEP}^{+/+}$mice (Figure 5). An inverse relationship of the NEP2 gene to $A \beta_{42}$ level was found in the hippocampi of 10-month-old NEP-lacking mice (Figure 5A). As the gene contributions of NEP2 decreased $\left(\mathrm{NEP} 2^{+/+}\right.$to $\mathrm{NEP} 2^{+/-}$to $\mathrm{NEP} 2^{-/-}$), hippocampal $A \beta_{42}$ levels increased. However, no similar effect was found when measuring $A \beta_{40}$ in the hippocampus at 10 months (Figure 5B). NEP/NEP2 DKO mice at 10 months of age showed increased $A \beta_{42}$ in the hippocampus and brainstem/diencephalon, relative to control

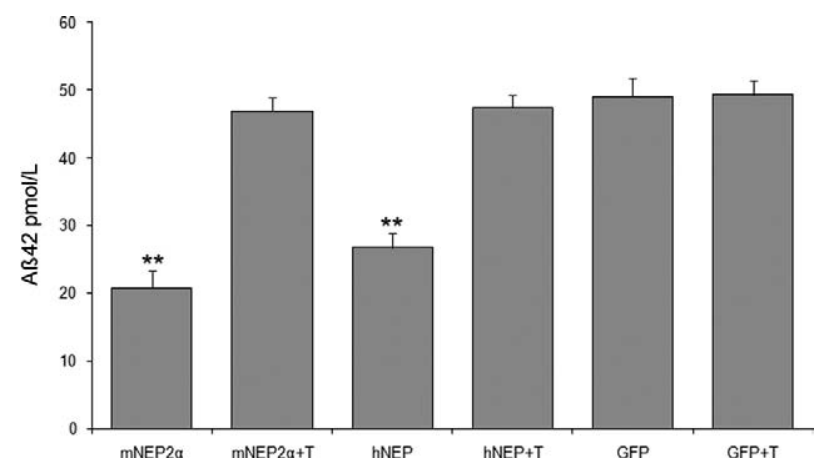

Figure 4. Murine NEP $2 \alpha$ degrades $\mathrm{A} \beta_{42}$. Quantitative analysis of remaining $\mathrm{A} \beta_{42}$ in conditioned cell culture medium containing $50 \mathrm{pmol} / \mathrm{L} \mathrm{A} \beta_{42}$ after incubation (5 hours) with HEK293T cells transfected with endopeptidase expressing plasmids (mNEP2 $\alpha$, hNEP) or control plasmid (green fluorescent protein, GFP) in the presence $(+\mathrm{T})$ or absence of thiorphan $(100 \mu \mathrm{mol} / \mathrm{L})$ $(n=4)$. Values are averages \pm SEM. ${ }^{* * *} P<0.01$ compared with GFP. 
A

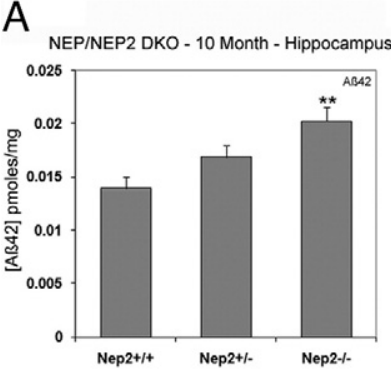

B

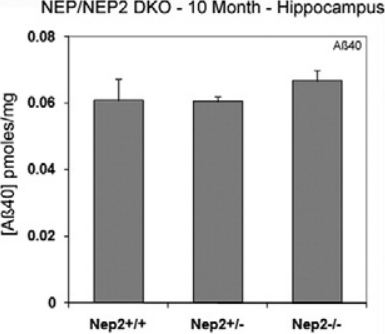

C

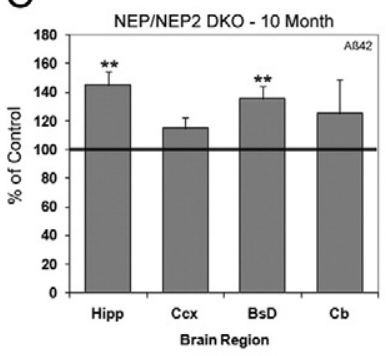

D

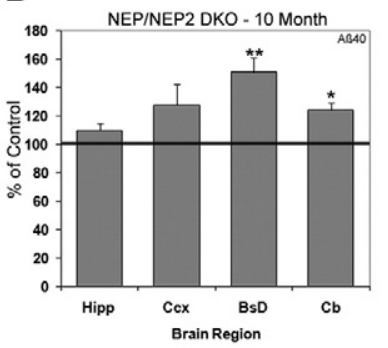

$E$

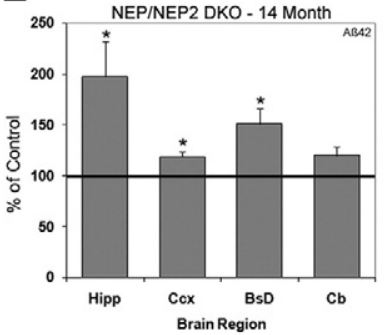

$\mathrm{F}$

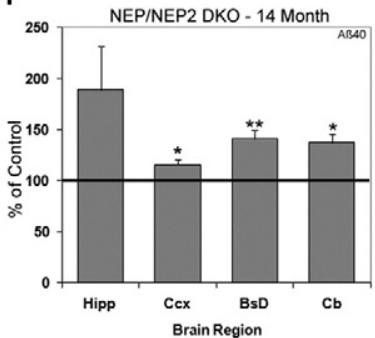

Figure 5. A $\beta$ levels are increased in the absence of NEP2 in NEP KO mice. Total $\mathrm{A} \beta_{42}(\mathbf{A})$ and $\mathrm{A} \beta_{40}(\mathbf{B})$ in the hippocampus of 10-month-old NEP KO mice homozygous $(n=8)$, heterozygous $(n=5)$, and deficient $(n=10)$ for the NEP2 gene. Relative levels of $\mathrm{A} \beta_{42}(\mathbf{C}, \mathbf{E})$ and $\mathrm{A} \beta_{40}(\mathbf{D}, \mathbf{F})$ from 10-monthold $(\mathbf{C}, \mathbf{D})$ and 14-month-old $(\mathbf{E}, \mathbf{F})$ NEP/NEP2 DKO mice reported as a percentage of control ( $\mathrm{NEP}^{-/-} / \mathrm{NEP} 2^{+/+}$) mice from hippocampus (Hipp), cerebral cortex (Ccx), brainstem/diencephalon (BsD), and cerebellum (Cb) For the 14-month group, $n=9$ for NEP2 $2^{+/+}$and $n=7$ for NEP2 ${ }^{-/-}$. Values are averages \pm SEM. ${ }^{*} P<0.05,{ }^{* *} P<0.01$.

$\left(\mathrm{NEP}^{-/-} / \mathrm{NEP}^{+/+}\right)$mice. Levels of $\mathrm{A} \beta_{40}$ were increased in the brainstem/diencephalon and cerebellum (Figure 5, $\mathrm{C}$ and $\mathrm{D})$. At 14 months, the elevated levels of $A \beta_{42}$ in the hippocampus increased approximately twofold, and both $A \beta$ isoforms were elevated in most brain regions (Figure 5 , $E$ and $F$ ). Despite elevated levels of $A \beta$, immunohistochemistry of brains from 14-month-old DKO mice showed no evidence of plaque deposition (data not shown).

\section{Increased A $\beta$ Levels In Phosphoramidon-Treated NEP/NEP2 DKO Mice}

To determine whether NEP/NEP2 DKO mice are still sensitive to NEP-like endopeptidase inhibitors, phosphoramidon was infused intracerebroventricularly using miniosmotic pumps. Phosphoramidon-infused mice showed elevated levels of $A \beta_{42}$ or $A \beta_{40}$ in most brain regions compared with controls treated with i.c.v. saline (Figure $6, A$ and $B$ ). $A \beta_{42}$ levels were significantly elevated in the cortex and cerebellum; $A \beta_{40}$ levels showed significant increases in all brain regions except the brainstem/dien-

cephalon. These data indicate that phosphoramidonsensitive endopeptidase activity against $A \beta$ remains in the absence of NEP2 and NEP

\section{Discussion}

Through the use of knockout and transgenic technology, the present findings demonstrate the importance of the endopeptidase NEP2 in the A $\beta$ clearance pathway. The results from three mouse lines (NEP2 KO, NEP/NEP2 DKO, and $\mathrm{APPtg} / \mathrm{NEP} 2 \mathrm{KO}$ ) demonstrated elevations in both $\mathrm{A} \beta_{42}$ and $A \beta_{40}$ in various brain regions analyzed at multiple time points. For NEP2 KO mice, the regions of highest $A \beta$ elevations were the hippocampus and brainstem/diencephaIon. The magnitude of $A \beta$ elevation (1.5-fold) in the hippocampus is similar to that reported for NEP KO mice. ${ }^{4}$ Although $A \beta_{42}$ in the hippocampus and both $A \beta_{42}$ and $A \beta_{40}$ in the brainstem/diencephalon showed elevations, there was a modest reduction in $A \beta_{40}$ levels in the cerebellum, compared with wild-type mice (Figure 1D). One possible explanation for this observation is enzymatic up-regulation of alternative $A \beta$-degrading endopeptidases in response to NEP2 deficiency in these regions. Up-regulation of these alternative enzymes may be sufficient to compensate for the increases in $A \beta$ due to NEP2 deficiency.

Although the NEP2 KO data clearly showed a significant role for NEP2 in endogenous $A \beta$ regulation, the effect of NEP2 on $A \beta$ degradation when challenged with a high level of $A \beta$ remained to be determined. This issue was addressed with the use of APPtg mice, which dramatically overproduce $A \beta{ }^{20}$ In combination with the APP transgene, NEP2 deficiency produced more dramatic elevation in $A \beta_{40}$ levels, strongly supporting a role for NEP2 in $A \beta$ regulation (Figure 2). Although no elevations in $A \beta$ were seen in the cerebral cortex of NEP2 KO mice (Figure 1), a dramatic increase in plaque deposition was observed in the cerebral cortex of APP transgenic/NEP2 KO mice (Figure 3). This could be explained if the compensating mechanism that occurs in the cortex of singleknockout mice were somewhat limited in capacity. Thus, when challenged by very high levels of $A \beta$, this compensation is overcome, resulting in considerable accumulation in $A \beta$. Also, it should be noted that APP/A $\beta$ expres-
A

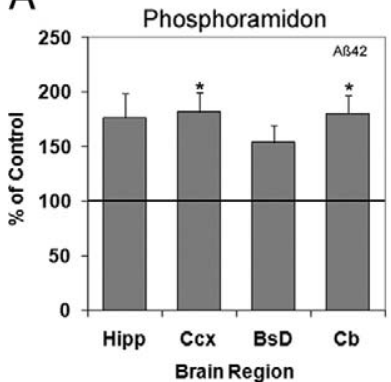

B

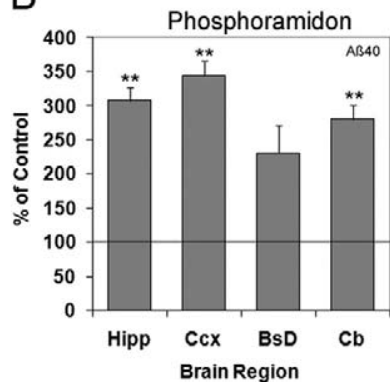

Figure 6. Increased $\mathrm{A} \beta$ levels after phosphoramidon administration in NEP/ NEP2 DKO mice. Relative levels of $\mathrm{A} \beta_{42}(\mathbf{A})$ and $\mathrm{A} \beta_{40}(\mathbf{B})$ in DKO mice (10 months old, $n=3$ ) infused with phosphoramidon (i.c.v., $10 \mathrm{mmol} / \mathrm{L}, 0.11$ $\mu \mathrm{L} / \mathrm{hr}$ ). Data are presented as the percentage of control (saline) $\mathrm{A} \beta$ levels from the hippocampus (Hipp), cerebral cortex (Ccx), brainstem/diencephalon (BsD), and cerebellum $(\mathrm{Cb})$. Values are means \pm SEM. ${ }^{*} P<0.05,{ }^{* * *} P<0.01$. 
sion levels in APP transgenics are also dependent on the transgene promoter and genomic integration site. The APP transgenic line we have used is reported to express APP/A $\beta$ more strongly in the cerebral cortex. ${ }^{20}$

The accumulation of intracellular $A \beta$ has been implicated as a major mediator of $A \beta$ toxicity. ${ }^{25}$ Our analysis of intracellular $A \beta$ did not show significant increases in intracellular accumulation (see Supplemental Figure S3, at $h$ ttp://ajp. amjpathol.org). The lack of a clear effect of NEP2 deficiency on intracellular $A \beta$, compared with plaque deposition, may be due to saturation of the intracellular $A \beta$ accumulation process. This hypothesis suggests that, even in the presence of the NEP2 gene, A $\beta$ levels are dramatically elevated in this transgenic model, resulting in high levels of intracellular $A \beta$ that are difficult to elevate further. Also, the contribution of cellular APP and its other fragments complicates this analysis. Finally, one limitation of the present study is that our analysis quantified total $A \beta$ and did not specifically measure aggregated forms of $A \beta$, including toxic soluble oligomers. ${ }^{26}$ This analysis has important implications for the ultimate relevance of NEP2 to AD, and we plan to address it in future studies.

Analyzing $A \beta$ levels in NEP2 KO mice also deficient for NEP provides further insight into the role of these key endopeptidases in A $\beta$ catabolism. The results from NEP/ NEP2 DKO mice indicate that ablation of the NEP2 gene leads to further elevated $A \beta_{42}$ and $A \beta_{40}$ levels in the brain, compared with single knockout of NEP (Figure 5). Our analysis also confirms that ablation of NEP alone produces elevated $A \beta$ levels. For example, NEP KO mice $\left(\mathrm{NEP}^{-/-}\right.$.NEP2 $\left.{ }^{+/+}\right)$displayed approximately 1.5 to 2 times the $A \beta$ levels of wild-type mice (compare Figure 1 , $A$ and $B$, with Figure 5, A and B). In addition, the absence of NEP and NEP2 produces an additive elevation in $A \beta$, verifying that both endopeptidases cooperate to control $A \beta$ levels in the brain. Our analysis did not reveal a significant increase in $A \beta$ levels between 10-month-old and 14-month-old mice (data not shown). Previous studies have demonstrated that treating rodents with inhibitors of NEP/NEP2 (ie, phosphoramidon and thiorphan) produces more dramatic elevations in $A \beta$ (30- to 50fold). ${ }^{2,5,6}$ However, despite the lack of both NEP and NEP2 genes, only modest elevations in $A \beta$ peptides were observed in our double-knockout studies-well below known plaque-inducing levels. As expected, the immunohistochemical analysis of 14-month-old DKO mice did not show evidence of plaque deposition (data not shown). Therefore, other $A \beta$ clearing mechanisms must be compensating for the loss of both NEP and NEP2.

Supporting this theory, DKO mice treated with phosphoramidon produced increases in both $A \beta_{42}$ and $A \beta_{40}$ levels in certain brain regions (Figure 6). It should be noted that, considering the smaller pump size and shorter duration of this study, the values of $A \beta$ elevation due to phosphoramidon infusion were comparable to the values seen with lower doses previously used by Nisemblat and colleagues. ${ }^{6}$ These elevations in $A \beta$ resulting from the application of an NEP/NEP2 inhibitor suggest the existence of yet other NEPlike endopeptidases that are involved in $A \beta$ catabolism. Given that both NEP and NEP2 are M13 proteases, the exploration of other enzymes in this family that are sensitive to phosphoramidon may lead to the discovery of additional enzymes involved in $\mathrm{A} \beta$ metabolism. Possible enzymes cooperating with NEP and NEP2 include endothelin-converting enzymes (ECE), phosphate-regulating gene with homologies to endopeptidases on the $X$ chromosome (PHEX), and damage-induced neuronal endopeptidase (DINE). The ECE are clear candidates because they are sensitive to phosphoramidon. However, early studies using thiorphan infusion in rodents suggest that ECEs are not involved in the drug's effect on $A \beta .^{2,5} \mathrm{PHEX}$ and DINE share $39 \%$ and $36 \%$ identity to NEP, respectively. ${ }^{8}$ It should be mentioned that aminopeptidases or other $A \beta$-degrading enzymes may also be affected by the infusion of relatively large concentrations of NEP-like inhibitors in these experiments. It is worth noting that phosphoramidon produced stronger effects on $A \beta_{40}$ in the absence of both NEP and NEP2, suggesting that the remaining NEP-like activity may more efficiently degrade $A \beta_{40}$ compared with $A \beta_{42}$. It is possible, therefore, that NEP and NEP2 could be the major catabolic NEP-like enzymes (ie, phosphoramidon-sensitive enzymes) responsible for clearing $A \beta_{42}$.

Our analyses clearly demonstrate that murine NEP2 degrades both isoforms of $A \beta$. However, a previous study reported that murine NEP2 degrades $A \beta_{40}$ much more efficiently than does $A \beta_{42}{ }^{9}$ To address this issue, we constructed a murine NEP2 $\alpha$ expression vector. Our results, using $A \beta$-conditioned medium overlaid on cells transfected with our engineered murine NEP2 $\alpha$ construct, demonstrate the ability of mNEP2 $\alpha$ to degrade $A \beta_{42}$ in the extracellular compartment (Figure 4). A possible explanation for the observed differences between our findings and the previous study may be the different experimental designs used. The previous study measured the cleavage of A $\beta$ from enzymes extracted in membrane-bound fractions, ${ }^{9}$ as opposed to the present study's measurements using the enzyme expressed from cells in culture.

Besides identifying a novel NEP-like enzyme that controls $A \beta$ in vivo, our results have implications for potential therapeutic applications. Experiments using NEP gene therapy have been conducted in APPtg mice using a variety of systems to overexpress NEP [reviewed by Marr and Spencer $^{3}$ ]. The results of these therapeutic studies showed reduced plaque pathology and memory improvements in treated animals. ${ }^{21,27-35}$ However, because current approaches could ultimately be ineffective or produce unwanted side effects, ${ }^{36-38}$ more tools are always welcome in the search for therapies for $A D$, and exploration of the potential of NEP2 as a therapeutic agent is warranted.

In conclusion, we have demonstrated in three different mouse models that NEP2 is required for the endogenous regulation of $A \beta_{42}$ and $A \beta_{40}$ levels in the rodent brain. However, unlike the results of thiorphan and phosphoramidon infusion studies, only modest elevations in these peptides were observed in nontransgenic mice lacking NEP and NEP2, suggesting the existence of redundant proteolytic systems for controlling $A \beta$ levels. These systems may include the class of phosphoramidon-sensitive (NEP-like) enzymes. 


\section{Acknowledgment}

We thank Andrew Mensing for assistance with this work.

\section{References}

1. Brookmeyer R, Johnson E, Ziegler-Graham K, Arrighi HM: Forecasting the global burden of Alzheimer's disease. Alzheimers Dement 2007, 3:186-191

2. Iwata N, Tsubuki S, Takaki Y, Watanabe K, Sekiguchi M, Hosoki E Kawashima-Morishima M, Lee HJ, Hama E, Sekine-Aizawa Y, Saido TC: Identification of the major Abeta1-42-degrading catabolic pathway in brain parenchyma: suppression leads to biochemical and pathological deposition. Nat Med 2000, 6:143-150

3. Marr RA, Spencer BJ: NEP-like Endopeptidases and Alzheimer's Disease. Curr Alzheimer Res 2010, 7:223-229

4. Iwata N, Tsubuki S, Takaki Y, Shirotani K, Lu B, Gerard NP, Gerard C Hama E, Lee HJ, Saido TC: Metabolic regulation of brain Abeta by neprilysin. Science 2001, 292:1550-1552

5. Dolev I, Michaelson DM: A nontransgenic mouse model shows inducible amyloid-beta (Abeta) peptide deposition and elucidates the role of apolipoprotein $\mathrm{E}$ in the amyloid cascade, Proc Natl Acad Sci USA 2004, 101:13909-13914

6. Nisemblat $Y$, Belinson H, Dolev I, Michaelson DM: Activation of the amyloid cascade by intracerebroventricular injection of the protease inhibitor phosphoramidon. Neurodegener Dis 2008;5:166-169

7. Ikeda K, Emoto N, Raharjo SB, Nurhantari Y, Saiki K, Yokoyama M, Matsuo M: Molecular identification and characterization of novel membrane-bound metalloprotease, the soluble secreted form of which hydrolyzes a variety of vasoactive peptides. J Biol Chem 1999, 274:32469-32477

8. Ghaddar G, Ruchon AF, Carpentier M, Marcinkiewicz M, Seidah NG Crine P, DesGroseillers L, Boileau G: Molecular cloning and biochemical characterization of a new mouse testis soluble-zinc-metallopeptidase of the neprilysin family, Biochem J 2000, 347:419-429

9. Shirotani K, Tsubuki S, Iwata N, Takaki Y, Harigaya W, Maruyama K, Kiryu-Seo S, Kiyama H, Iwata H, Tomita T, Iwatsubo T, Saido TC: Neprilysin degrades both amyloid beta peptides 1-40 and 1-42 most rapidly and efficiently among thiorphan- and phosphoramidon-sensitive endopeptidases. J Biol Chem 2001, 276:21895-21901

10. Huang JY, Bruno AM, Patel CA, Huynh AM, Philibert KD, Glucksman MJ, Marr RA: Human membrane metallo-endopeptidase-like protein degrades both beta-amyloid 42 and beta-amyloid 40. Neuroscience 2008, 155:258-262

11. Raharjo SB, Emoto N, Ikeda K, Sato R, Yokoyama M, Matsuo M: Alternative splicing regulates the endoplasmic reticulum localization or secretion of soluble secreted endopeptidase. J Biol Chem 2001, 276:25612-25620

12. Oh-Hashi K, Ohkubo K, Shizu K, Fukuda H, Hirata Y, Kiuchi K: Biosynthesis, processing, trafficking, and enzymatic activity of mouse neprilysin 2. Mol Cell Biochem 2008, 313:103-111

13. Facchinetti $P$, Rose C, Schwartz JC, Ouimet T: Ontogeny, regional and cellular distribution of the novel metalloprotease neprilysin 2 in the rat: a comparison with neprilysin and endothelin-converting enzyme-1. Neuroscience 2003, 118:627-639

14. Ouimet T, Facchinetti P, Rose C, Bonhomme MC, Gros C, Schwartz JC: Neprilysin II: a putative novel metalloprotease and its isoforms in CNS and testis. Biochem Biophys Res Commun 2000, 271:565-570

15. Carpentier M, Marcinkiewicz M, Boileau G, DesGroseillers L: The neuropeptide-degrading enzyme NL1 is expressed in specific neurons of mouse brain. Peptides 2003, 24:1083-1091

16. Carpentier M, Guillemette C, Bailey JL, Boileau G, Jeannotte L, DesGroseillers L, Charron J: Reduced fertility in male mice deficient in the zinc metallopeptidase NL1. Mol Cell Biol 2004, 24:4428-4437

17. Rose C, Voisin S, Gros C, Schwartz JC, Ouimet T: Cell-specific activity of neprilysin 2 isoforms and enzymic specificity compared with neprilysin, Biochem J 2002, 363:697-705

18. Turner AJ, Nalivaeva NN: New insights into the roles of metalloproteinases in neurodegeneration and neuroprotection. Int Rev Neurobiol 2007, 82:113-135

19. Lu B, Gerard NP, Kolakowski LF Jr, Bozza M, Zurakowski D, Finco O, Carroll MC, Gerard C: Neutral endopeptidase modulation of septic shock. J Exp Med 1995, 181:2271-2275
20. Rockenstein E, Mallory M, Mante M, Sisk A, Masliaha E: Early formation of mature amyloid-beta protein deposits in a mutant APP transgenic model depends on levels of Abeta(1-42). J Neurosci Res 2001, 66:573-582

21. Spencer B, Marr RA, Rockenstein E, Crews L, Adame A, Potkar R, Patrick C, Gage FH, Verma IM, Masliah E: Long-term neprilysin gene transfer is associated with reduced levels of intracellular Abeta and behavioral improvement in APP transgenic mice. BMC Neurosci 2008, 9:109

22. Marr RA, Addison CL, Snider D, Muller WJ, Gauldie J, Graham FL: Tumour immunotherapy using an adenoviral vector expressing a membrane-bound mutant of murine TNF alpha. Gene Ther 1997, 4:1181-1188

23. Singer O, Marr RA, Rockenstein E, Crews L, Coufal NG, Gage FH, Verma IM, Masliah E: Targeting BACE1 with siRNAs ameliorates Alzheimer disease neuropathology in a transgenic model. Nat Neurosci 2005 , 8:1343-1349

24. Graham FL, van der Eb AJ: A new technique for the assay of infectivity of human adenovirus 5 DNA. Virology 1973, 52:456-467

25. Oddo S, Caccamo A, Shepherd JD, Murphy MP, Golde TE, Kayed R, Metherate R, Mattson MP, Akbari Y, LaFerla FM: Triple-transgenic model of Alzheimer's disease with plaques and tangles: intracellular Abeta and synaptic dysfunction. Neuron 2003, 39:409-421

26. Ashe $\mathrm{KH}$, Zahs KR: Probing the biology of Alzheimer's disease in mice. Neuron 2010, 66:631-645

27. El-Amouri SS, Zhu H, Yu J, Marr R, Verma IM, Kindy MS: Neprilysin: an enzyme candidate to slow the progression of Alzheimer's disease. Am J Pathol 2008, 172:1342-1354

28. Huang SM, Mouri A, Kokubo H, Nakajima R, Suemoto T, Higuchi M, Staufenbiel M, Noda Y, Yamaguchi H, Nabeshima T, Saido TC, Iwata $\mathrm{N}$ : Neprilysin-sensitive synapse-associated amyloid-beta peptide oligomers impair neuronal plasticity and cognitive function. J Biol Chem 2006, 281:17941-17951

29. Leissring MA, Farris W, Chang AY, Walsh DM, Wu X, Sun X, Frosch MP, Selkoe DJ: Enhanced proteolysis of beta-amyloid in APP transgenic mice prevents plaque formation, secondary pathology, and premature death. Neuron 2003, 40:1087-1093

30. Marr RA, Rockenstein E, Mukherjee A, Kindy MS, Hersh LB, Gage FH, Verma IM, Masliah E: Neprilysin gene transfer reduces human amyloid pathology in transgenic mice. J Neurosci 2003, 23:1992-1996

31. Poirier R, Wolfer DP, Welzl H, Tracy J, Galsworthy MJ, Nitsch RM, Mohajeri $\mathrm{MH}$ : Neuronal neprilysin overexpression is associated with attenuation of Abeta-related spatial memory deficit. Neurobiol Dis 2006, 24:475-483

32. Mohajeri MH, Wolfer DP: Neprilysin deficiency-dependent impairment of cognitive functions in a mouse model of amyloidosis. Neurochem Res 2009, 34:717-726

33. Madani R, Poirier R, Wolfer DP, Welzl H, Groscurth P, Lipp HP, Lu B, El Mouedden M, Mercken M, Nitsch RM, Mohajeri MH: Lack of neprilysin suffices to generate murine amyloid-like deposits in the brain and behavioral deficit in vivo. J Neurosci Res 2006, 84:1871-1878

34. Liu Y, Studzinski C, Beckett T, Guan H, Hersh MA, Murphy MP, Klein R. Hersh LB: Expression of neprilysin in skeletal muscle reduces amyloid burden in a transgenic mouse model of Alzheimer disease. Mol Ther 2009, 17:1381-1386

35. Guan H, Liu Y, Daily A, Police S, Kim MH, Oddo S, LaFerla FM, Pauly JR, Murphy MP, Hersh LB: Peripherally expressed neprilysin reduces brain amyloid burden: a novel approach for treating Alzheimer's disease. J Neurosci Res 2009, 87:1462-1473

36. lijima-Ando K, Hearn SA, Granger L, Shenton C, Gatt A, Chiang HC Hakker I, Zhong Y, lijima K: Overexpression of neprilysin reduces Alzheimer amyloid-beta42 (Abeta42)-induced neuron loss and intraneuronal Abeta42 deposits but causes a reduction in cAMP-responsive element-binding protein-mediated transcription, age-dependent axon pathology, and premature death in Drosophila. J Biol Chem 2008, 283 19066-19076

37. Meilandt WJ, Cisse M, Ho K, Wu T, Esposito LA, Scearce-Levie K Cheng IH, Yu GQ, Mucke L: Neprilysin overexpression inhibits plaque formation but fails to reduce pathogenic Abeta oligomers and associated cognitive deficits in human amyloid precursor protein transgenic mice. J Neurosci 2009, 29:1977-1986

38. Walther T, Albrecht D, Becker M, Schubert M, Kouznetsova E, Wiesner B, Maul B, Schliebs R, Grecksch G, Furkert J, Sterner-Kock A, Schultheiss HP, Becker A, Siems WE: Improved learning and memory in aged mice deficient in amyloid beta-degrading neutral endopeptidase. PLoS One 2009, 4:e4590 